\title{
ON THE ASSOCIATIONS AND ORIGIN OF THE NONTITANIFEROUS MAGNETITES IN THE ADIRONDACK REGION.
}

\author{
David Hale Newland. \\ INTRODUCTION.
}

The rounded area of Precambric crystalline rocks that may be comprehended under the name Adirondack region is divisible for considerations of economic geology into two portions which correspond with the unequal distribution of the rock formations. The core of the region is made up of a great mass of basic plutonic rocks situated to the east and somewhat north of the central part and including about $\mathrm{I}, 200$ square miles. Within this area titaniferous magnetites are the only mineral deposits of known importance. The surrounding region, which has a surface of over I0,000 square miles, is made up mainly of metamorphosed sediments and local igneous intrusions of acidic nature; it contains the nontitaniferous magnetites, as well as other valuable minerals including hematite, garnet, graphite, pyrite, feldspar, talc, etc., in workable bodies.

The nontitaniferous magnetites are aggregated along the margin of the northern half of the region. They have been mined at a great number of localities, operations having been carried on during the whole of the last century, with few interruptions, and have furnished a total of over $35,000,000$ tons of iron ore. The greater part of the present output consists of concentrates made from phosphoric and lean ores formerly of little value. The resources of this character are extensive. With the falling off in the iron content of Lake Superior ores in recent years, these concentrates have been eagerly sought by eastern furnaces as a basis for mixture, since they have a constant average of about 65 per cent., while the low phosphorus and Bessemer grades which are also produced find a ready market. 


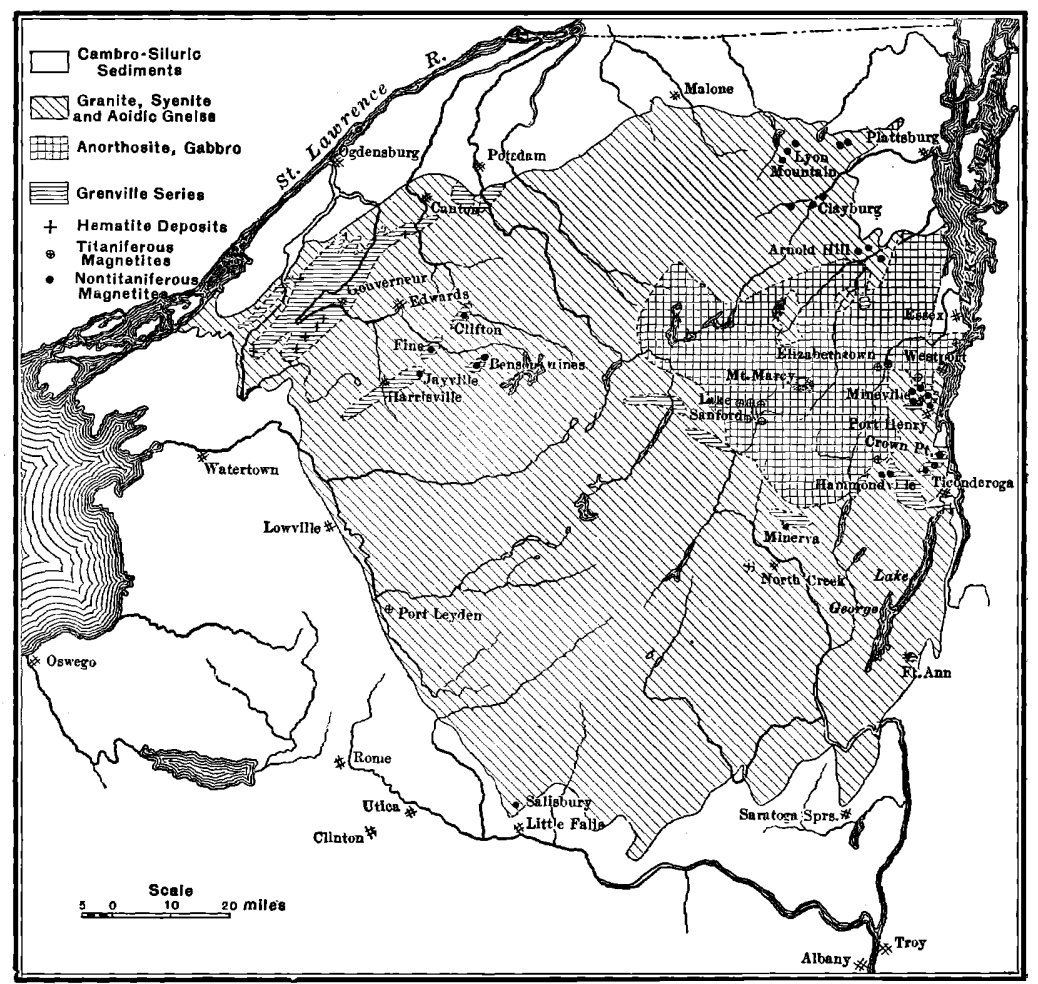

FIG. 80. Sketch Map of the Adirondack Region showing Iron-Ore Deposits.

\section{GEOLOGY.}

GEOLOGICAL HISTORY.

The geological history of the region is exceedingly complex. Its study and interpretation have progressed materially only during the last decade since the inauguration of a consistent plan of field work by the New York State Geologist. A large assemblage of facts relating to the character and succession of the formations has been made, chiefly by H. P. Cushing, J. F. Kemp and C. H. Smyth, Jr. The preparation of detailed areal maps is now under way.

Of the various formations represented, only those of Precambric age have any direct bearing upon the magnetites and need to be considered here. It may be mentioned, however, 
that the area is completely bordered by Paleozoic strata, ranging from the Potsdam sandstone to the Utica shale, which also occur occasionally in the interior as small disconnected patches. A time interval of long duration ensued after the metamorphism of the Precambrics, during which the region was levelled off before it began to be submerged beneath the Paleozoic sea. Glacial materials are everywhere present, mantling even the slopes of the highest mountains.

\section{GRENVILLE SERIES.}

So far as known the oldest rocks of the Adirondacks are represented by a succession of crystalline limestones, banded hornblende and biotite gneisses, pyritic and garnetiferous schists, amphibolites and quartzites. They are unequally distributed, usually as belts interfolded with the other formations. They are undoubtedly ancient sediments and have been correlated with the similar series of Grenville rocks in Canada. Little has been learned as to the thickness of the series, or the relative order of their occurrence; and though there must have been a basement on which they were deposited, it has not thus far been discovered.

IGNEOUS INTRUSIONS.

The plutonic rocks can be divided into four great groups: Anorthosite, gabbro, syenite and granite.

Anorthosite.-The anorthosite appears to have been the first in time. It occupies nearly all of the central area above mentioned. Though normally a practically pure labradorite rock of porphyritic habit, not infrequently the ferromagnesian minerals assume such importance that it would be classed as a gabbro or norite, to which there is likewise a resemblance in texture.

Gabbro.-Aside from such gabbroic phases of the anorthosite, there are separate intrusions of gabbro as dikes and bosses, clearly of much later date. They occur mainly in the central part, and are scarcely represented at all in the southern and western Adirondacks.

Syenite.-The Adirondack syenite constitutes a peculiar variety of that rock and was not recognized as such until recently. 
With its dioritic phase, it may be said to occupy a middle place between the gabbros and granites. Green augite, with accessory hypersthene and hornblende, and magnetite are the dark constituents. The feldspar is prevailingly microperthite, though orthoclase and oligoclase are generally present. On fresh surfaces the color is green, varying from light to dark shades. When there is a considerable proportion of the dark minerals, the rock resembles the gabbros so closely as to be indistinguishable in hand specimens. With the increase in these minerals there is likely to be also a change in the feldspar, shown by the preponderance of plagioclase. It is not apparent, however, that the syenite actually merges into gabbro, the evidence tending to show that the two belong to separate periods of intrusion.

Granite.-Granites with their derived gneisses, are perhaps the most frequent of all the plutonic rocks. Over large areas they are the only igneous formation present. They are prevailingly grayish or reddish in color. Feldspar and quartz always predominate and may constitute nearly the entire mass. Hornblende granite seems to be more common than the mica varieties, while augite granite occurs as a variation of the syenite. The granites apparently are of different ages.

Gneisses.-All of the intrusives named are found with laminated and cataclastic textures, perfectly massive varieties being the exception. In regions where compression and crushing have been extreme, the resultant gneisses present very difficult problems to the field geologist, and more since they are often intimately involved with the sedimentary gneisses.

Gneisses of Doubtful Relationships.-There are some areas in the Adirondacks underlain by gneisses that have not yet been demonstrated to belong with either of the foregoing groups. Professor Cushing has called attention to a belt on the northern border, composed mainly of red quartzose gneisses and gray feldspathic varieties, with interfolded lenses of dark hornblende gneisses or amphibolites. There are few exposures of the Grenville throughout the belt which is some seventy miles long.

Professor Cushing ${ }^{-1}$ is inclined to regard the series as older

${ }^{1}$ Geology of the Northern Adirondack Region. Bulletin 95, N. Y. State Museum. 
than the recognized intrusives and has proposed to group them tentatively under the name of Saranac formation. It is probble that if there is anywhere a remnant of the basal rocks, it will be found in this group. Yet a part of the formation undoubtedly consists of igneous derivatives as the writer has found in examination of the areas around Lyon Mountain and Arnold hill where there are granitic cores of massive and even porphyritic character, resembling in all respects the normal intrusives.

Dike Rocks.-Diabase dikes are frequent in the eastern and northern Adirondacks and are often encountered in the mines. They are the freshest of the igneous rocks, having been intruded in late Precambric time. They may mark lines of faulting, though the displacements that occur along them are usually small.

THE ORE DEPOSITS.

CHARACTER OF THE MAGNETITES.

The nontitaniferous magnetites exhibit a wide variety of composition. The lean ores are disseminations of magnetite in the country rocks, and contain quartz, feldspar, pyroxene, hornblende, etc., in greater or less amount. From these impure aggregates may be traced a series of gradations into pure magnetite. The richest ores carry 60 to 70 per cent. Fe. They are obtained principally at Mineville, though the Hammondville and Arnold hill mines have supplied considerable quantities in the past. Ores with less than 50 per cent. Fe are generally too refractory for direct smelting; their utilization depends upon concentration to which they are very adaptable in most cases. The lowest grade of milling ore carries about 35 per cent. Fe.

According to the percentage of phosphorus, the magnetites may be- divided into low-phosphorus, Bessemer and highphosphorus grades. In some localities, Mineville, for example, Bessemer and high-phosphorus ores have been produced from contiguous deposits, but generally the ores from one locality show a fair degree of uniformity in respect to phosphorus. The bulk of the low-phosphorus ores has come from Lyon Mountain where concentrates are made that carry about .008 per cent. with 65 per cent. Fe, a grade that competes with the best of foreign ores. 
The crude non-Bessemer magnetites carry as much as 2 per cent. $\mathrm{P}$, corresponding to Io per cent. apatite which is the containing mineral.

Admixture with pyrite and more rarely pyrrhotite is the source of the sulphur in the ores. The part played by these minerals seems to depend primarily upon the geological associations of the ore bodies, the existence of more than a fraction of one per cent. or so of sulphur is limited to the deposits found in the dark gneisses and schists of the Grenville which are themselves impregnated with pyrite. When the wall rock is an acid variety corresponding to granite or syenite in mineral composition, pyrite is a very subordinate constituent.

Local variations in the ores may arise from the association of pegmatite carrying magnetite in quantity to make it valuable. The pegmatite has an additional interest as a source of wellcrystallized and rare minerals.

Alteration of the magnetites may give rise to pseudomorphic hematite or martite. This mineral occurs sparingly in several deposits but in quantity only on Arnold hill where the so-called "blue veins" are almost pure hematite. In the immediate vicinity are bodies of unchanged magnetite, so that the alteration seems to have been brought about by a local agency, probably underground waters circulating along conveniently disposed fissures or faults.

FORM OF THE ORE BODIES.

In general the deposits have a much greater extent parallel to the strike and dip of the enclosing rocks than at right angles thereto and show a lenticular form in cross-section. In some cases they are so prolonged on the line of strike that they are better described as tabular bodies, forms that have been held to be indicative of stratified arrangement. The greatest variations from these forms are found in the eastern Adirondacks. There the ore bodies often exhibit a complexity of pinches, swells and compressed folds that afford puzzling structural problems.

There can be no doubt that the form assumed by the ore bodies is conditioned by the structures of the enclosing rocks. When the latter are foliated to an extent that permits observations of 
dip and strike, the contours follow closely the changes, even the subordinate ones. The ores consequently must have been deposited before the regional metamorphism took place, or at least before the rocks received their present structural arrangement. They have passed through all the vicissitudes of squeezing and deformation impressed upon the walls.

GEOLOGICAL OCCURRENCE OF THE DEPOSITS.

There is no single rock type or formation characteristic of the magnetites as a whole. The wall rocks in the different localities include almost the entire range of Adirondack formations, the basic igneous ones excepted. Acidic gneisses of igneous character constitute the country rock of the Clinton county mines, all of which occur within the great gneiss belt of the Saranac formation. At Lyon Mountain the ore is nothing more than a dissemination of magnetite in a zone of the country rock which here is a massive variety containing microperthite, oligoclasse, green augite, hornblende and quartz. The zone has been traced for six miles and ranges from 20 to 200 feet wide. It is divided into two or three parallel bands at times by intercalations of wall rock into which the ore shades off at the sides. The average ore as mined carries 50 to 60 per cent. magnetite, the rest being rock matrix. Mineralogically the wall rock lies on the border between the granites and the syenites, while local phases may have the composition of either. It is interfolded with bands of hornblende schist which it has penetrated and more or less absorbed into its mass. Pegmatite of the same composition occurs in great abundance, but rarely in dike form.

The numerous deposits centering around Arnold hill and Palmer hill in southern Clinton county are not materially different. The Palmer hill locality has interest, however, from the fact that the ore and rock at times carries a proportion of fluorite as an intercrytallization with the other components. Its presence can hardly be explained except by pneumatolytic action in the cooling of an igneous mass. Fluorite is a quite common mineral in the magnetites elsewhere, but its occurrence is limited so far as observed to pegmatite and vein material. The country rock is 
uniformly an alkali-feldspar quartz aggregate, rich in magnetite and carrying augite, hornblende or biotite as ferromagnesian minerals. Massive varieties are frequent.

In the important Mineville group of Essex county, the ore bodies are closely associated with augite syenite of the usual Adirondack type. Recent explorations conducted by drilling have shown the syenite to underlie the main deposits in what seems to be a continuous mass. The rock is of greenish cast, normally composed of microperthite, augite, hornblende and magnetite, but, through the addition of quartz and shrinkage of the ferromagnesian minerals, passes into a lighter grayish or reddish rock much like the varieties found in Clinton county. The latter type forms the hanging wall of the Old Bed mines, the largest in the Adirondacks. Its relations to the underlying syenite, as well as the apparent differentiation of the syenite into a dioritic phase that occurs in close relation to the Barton hill group have been described by Professor J. F. Kemp in an article soon to be published. ${ }^{1}$

A basic type of angite syenite constitutes the walls of the mine near Salisbury, Herkimer county, being a part of the intrusives in that region which reach southward from the Adirondacks into the Mohawk valley. The dark minerals (augite, hornblende and magnetite) constitute about 75 per cent. of the rock in immediate - contact with the ore but away from the latter there is a gradual change into the normal syenite.

The occurrence of magnetites in the Grenville gneisses and schists is characteristic for the St. Lawrence county mines, as well as for some in southern Essex county, notably around Crown Point. Compared with the above described deposits, their most striking peculiarity is the association of pyrite which brings the sulphur content up to considerable proportions and has been a drawback to their development in the past. The pyrite is very likely due to original organic matter in the sandstones, shales and limestones from which the present rocks have been derived. The widespread occurrence of graphite in the same series is noteworthy.

${ }^{1}$ Included in a report on the Adirondack magnetites under publication by the New York State Museum. 
At Benson Mines, St. Lawrence county, the magnetite body is an impregnated zone in a quartzose banded gneiss that contains sillimanite and scapolite in addition to feldspar. The dark minerals are hornblende, biotite and augite. Garnet and pyrite are richly represented in places. The alternation of light and dark bands corresponding to variations in the mineral proportions is a prominent feature, suggestive of original changes in sedimentation.

The Clifton mines north of Benson and those near Fine are found within a black hornblende schist that contains interbedded layers of crystalline limestone. This rock occurs in force as the wall of one of the openings at Clifton.

At Jayville, west of Benson mines, the Grenville series is in evidence, though here the ore bodies and walls (hornblendebiotite schist) have been invaded from below by a later hornblende granite which has broken up what was apparently a continuous bed into numerous lenses and shoots that seem to have given out in depth after passing the limits of the schist. The effects of the invasion are noticed in the coarse crystallization, of the magnetite and in the formation of interlocking masses of hornblende as well as abundant titanite. Pyrite is much less abundant than is usual with the ores found elsewhere in the Grenville.

ORIGIN OF THE MAGNETITES.

The association of the magnetites with both igneous and sedimentary formations must be obviously considered in attempting to explain their genesis.

For the occurrences in the midst of plutonic masses, which have been found to be the prevailing type in the eastern Adirondacks, there would seem to be no escape from the conclusion that the ores have originated within the wall rocks themselves. The precise manner in which they were brought into their present position may have varied in different localities. Magmatic differentiation was probably an important factor in the early stages and may account for the whole course of their development in some cases. Yet the occurrence of fluorite, apatite, hornblende and other minerals of this class, intercrystal- 
lized with the magnetite, cannot be disregarded, nor the frequent accompaniments of pegmatite and vein quartz, all of which are suggestive of mineralizing agencies. Gaseous and water circulations set up by the cooling of the rocks have no doubt helped to assemble some of the ore bodies, like those of Palmer hill, Mineville and Lyon Mountain.

The application of the principle of magmatic segregation to ore bodies in rocks of syenitic and granitic composition may be questioned by some investigators, but in the present case there is valid evidence for its support. The rocks of the Adirondacks contain a large excess of iron over the amounts combined with the lime and magnesia in the form of silicates. In a recent report, Professor Cushing ${ }^{1}$ has published the results of chemical and mineralogic analysis of granites and syenites from a number of localities. With silica percentages ranging from 54.10 per cent. to 68.50 per cent., the amounts of magnetite present as such vary from a maximum of 6.57 per cent. to a minimum of 1.58 per cent. The relative proportions of free iron, which would seem to be the important element to be considered, compare with those found in the gabbros and anorthosites. With 5 per cent. magnetite in the rock a concentration of IO: I would produce the leaner ores that are mined in the region.

Taking the titaniferous deposits into account, as well, a continuous series can be established for the igneous rocks from the acid to the basic ends. In the first instance all may have come from a common magma. The fact of the intimate relation existing between the intrusive rocks has been brought out by recent petrographic studies and there is reason for believing that they represent successive cleavages of a once continuous mass in the interior. The ores included by the acid and basic varieties differ mainly in their titanium content. In the silicious rocks the titanium has combined with lime and silica to form titanite which has been held mainly in the body of the mass. With the basic magmas, the silica has been entirely taken up by the feldspathic and ferromagnesian constituents, and the titanium consequently has united with the iron and become concentrated with it in the

\footnotetext{
${ }^{1}$ Geology of the Long Lake Quadrangle. Bulletin II5, N. Y. State Museum.
} 
ore bodies. The ores in the granites and syenites commonly contain a fraction of one per cent. or so of titanium in the form of titanite.

The pyritic ores in the Grenville series belong of course to a separate class. They may be ascribed possibly to some process of chemical or mechanical sedimentation, such as has been proposed by different writers on the magnetites of the eastern United States, but the evidences presented in favor of that derivation can not be considered to have compelling force when applied to the Adirondack occurrences. The deposits are not so regular in form or persistent along definite geological horizons as one would expect of stratified bodies. The hanging and foot walls rarely show any marked differences of composition that could be referred to changes of sedimentation. The thickness of some of the deposits is excessive when compared with known examples of bedded occurrences; the Benson body for instance measures over 200 feet across the strike and the country rock, judging from the results of magnetic surveys, must be mineralized over a considerably greater width. In general the deposits have no sharply defined bounds, but shade off at the edges, while they may wedge out or terminate quite abruptly at the ends.

Though it is believed they are epigenetic deposits, the basis of known facts is so slender that any conclusion as to the precise mode of derivation must be largely hypothetical. The, view that the ores were formed before the surrounding rocks had undergone their final compression and folding appears reasonable, because they have laminated textures and conform in their arrangement to the general field structures. Their introduction may thus have taken place before the period of general metamorphism, in which case it might have been accomplished by underground circulations, with limonite or carbonate replacing the original shales and limestones as the first step. The presence of organic matter in the beds, indicated by their content of graphite and pyrite, would exercise a reducing effect, favorable to the formation of magnetite rather than hematite under the ensuing metamorphic conditions. 